\title{
SUNSHINE POLICY: KEBUNTUAN CONFIDENCE BUILDING MEASURES SEMENANJUNG KOREA PADA MASA KIM DAEJUNG- ROH MOOHYUN
}

\author{
Bayu Eko Yulianto ${ }^{1}$ \\ ${ }^{1}$ Departemen Hubungan Internasional Fakultas Ilmu Sosial \& Ilmu Politik \\ Universitas Indonesia, \\ bayu.eko91@ui.ac.id
}

\begin{abstract}
This paper describes the ineffectiveness of South Korea's confidence-building measures towards North Korea during the reign of Kim Dae Jung and Roh Moo Hyun through the sunshine policy. The previous studies on the sunshine policy only discussed the efforts made by the South Korean government through the sunshine policy and America's influence on the implementation in general. The studies are divided into three major categories namely: domestic politics, political economy, and regional studies, but none has discussed the causes of the ineffectiveness of the sunshine policy. By using confidence-building measures as an analytical framework, this paper will explain the variables in confidence-building measures that cause sunshine policies to be ineffective. The main argument of this paper is that there are 2 factors that cause the sunshine policy to be ineffective, namely the influence of America and the absence of political will from North Korea to achieve the goal of confidence-building measures through sunshine policy.
\end{abstract}

Keywords: South Korea, North Korea, America, Confidence Building Measures (CBMs), Political Will

\section{PENDAHULUAN}

Keamanan suatu negara atau kawasan dipengaruhi oleh negara-negara lain yang saling berbatasan maupun berada di suatu kawasan yang sama. Terdapat berbagai ancaman terhadap keamanan tersebut, salah satunya adalah potensi terjadinya interstate war khususnya bagi negara yang belum mencapai perdamaian yang permanen. Salah satu contohnya adalah situasi di Semenanjung Korea. Sejak gencatan senjata Perang Korea pada tahun 1953, ketegangan antara Korea Selatan dan Korea Utara di Semenanjung Korea masih berlanjut sampai saat ini.

Hal tersebut disebabkan oleh arms race antara Korea Selatan dan Korea Utara yang terus berlanjut serta pengaruh yang diberikan oleh pihak ketiga seperti Amerika dalam hubungan Korea Selatan dan Utara. Rasa saling tidak percaya dan 
kecurigaan yang terdapat di antara Korea Selatan dan Korea Utara juga menjadi penyebab utama dari ketegangan tersebut. Korea Selatan pada masa pemerintahan Kim Dae Jung dan Roh Moo Hyun telah melakukan berbagai upaya untuk meredakan ketegangan tersebut. Salah satu upaya yang dilakukan adalah Confidence Building Measures (CBMs) melalui "Sunshine Policy".

"Sunshine Policy" merupakan kebijakan rekonsiliasi dan kerjasama Korea Selatan terhadap Korea Utara yang dijalankan selama 10 tahun pada masa kepresidenan Kim Dae Jung dan Roh Moo Hyun (1998-2008). Selain tujuan jangka panjang yaitu reunifikasi, tujuan utama "Sunshine Policy" sebagai upaya CBMs adalah meningkatkan interaksi dan kerja sama dalam berbagai bidang yang meliputi ekonomi, sosial dan keamanan untuk menciptakan stabilitas dalam hubungan Inter-Korea. Tetapi "Sunshine Policy" gagal membawa kestabilan di Semenanjung Korea meski dijalankan secara konsisten di berbagai bidang selama 10 tahun. Justru hubungan antara Korea Selatan dan Korea Utara semakin tegang dengan uji coba senjata nuklir Korea Utara pada tahun 2006 (Ryu, 2009).

Berbagai kajian akademis mengenai "Sunshine Policy" telah dilakukan baik oleh peneliti Indonesia maupun oleh peneliti Korea Selatan dan negara lain. Secara garis besar, kajian-kajian terdahulu dapat dibagi ke dalam tiga kategori besar yaitu (1) Politik Domestik, (2) Ekonomi-Politik, dan (3) Kajian Kawasan.

Kajian yang menggunakan perspektif Politik Domestik pada dasarnya menggunakan beberapa konsep yaitu National Security (Han, 2002), Domestic Consensus (Moon, 2001), Sociology of Trust (Kudlacova, 2014), Structural Constraint (Paik, 2002), Spillover Effect (Kim, 2014), Negotiated Settlement (Lee \& Moon, 2003), Game Theory (Heo \& Chong, 2001), Arms Race (Moon \& Lee, 2009), Regime Survival (Mun, 2001), dan Denuclearization (Haggard \& Noland, 2008) untuk membahas upaya CBMs Korea Selatan terhadap Korea Utara. Berdasarkan konsep-konsep di atas upaya CBMs dapat berjalan efektif jika terdapat perpaduan antara upaya Arms Control, engagement policy serta dukungan domestik dari Korea Selatan.

Sedangkan kajian yang menggunakan perspektif Ekonomi Politik membahas tentang Economic Dependency (Hwang, 2013), Economic Reform (Beck \& Reader, 2005), dan Korea's Divided Families Reunion (Foley, 2003). Kajian dengan perspektif Ekonomi Politik berpendapat bahwa adanya upaya dari Korea Selatan yang 
mencoba memperluas pengaruhnya terhadap Korea Utara melalui bantuan dan kerja sama ekonomi. Upaya CBMs Korea Selatan tentu dipengaruhi oleh berbagi aktor internasional lainnya, hal tersebut terlihat dalam kajian terakhir yaitu kajian yang menggunakan perspektif Kawasan yang memperlihatkan pengaruh besar Amerika (Olsen, 2003 ; Cha \& Kang, 2004) dalam CBMs Korea Selatan. Amerika memiliki pengaruh yang besar terhadap pembuatan kebijakan Korea Selatan.

Kajian terdahulu yang terbagi dalam tiga kategori tersebut menjelaskan ketegangan dalam Semenanjung Korea serta berbagai upaya yang telah dilakukan oleh Korea Selatan dan pengaruh dari aktor internasional dalam hubungan Korea Selatan dan Korea Utara. Namun kajian-kajian tersebut tidak menjelaskan secara khusus mengapa upaya-upaya untuk meredakan ketegangan di Semenanjung Korea pada masa pemerintahan Kim Dae Jung dan Roh Moo Hyun tidak menghasilkan hasil yang diharapkan meskipun engagement policy yang dilakukan secara konsisten. Kajian terhadap upaya CBMs pada masa pemerintahan Kim Dae Jung dan Roh Moo Hyun menjadi penting untuk dibahas sebab pada masa pemerintahan tersebut terjadi perubahan kebijakan Korea Selatan terhadap Korea Utara yang sebelumnya adalah hardline policy menjadi reconciliation policy. Pertemuan antara pemimpin Korea Selatan dan Korea Utara pertama kali terjadi pada masa pemerintahan Kim Dae Jung dan dilanjutkan oleh pemerintahan Roh Moo Hyun. Sehingga masa pemerintahan Kim Dae Jung dan Roh Moo Hyun menjadi titik balik untuk hubungan antara Korea Selatan dan Korea Utara.

Untuk itu tulisan ini akan menggunakan konsep CBMs, untuk menjelaskan alasan "Sunshine Policy" pemerintahan Kim Dae Jung dan Roh Moo Hyun tidak efektif dalam meredakan ketegangan di Semenanjung Korea. Sehingga tulisan ini mengangkat pertanyaan mengapa upaya Confidence Building Measures (CBMs) Korea Selatan pada masa pemerintahan Kim Dae Jung dan Roh Mu hyun terhadap Korea Utara melalui "Sunshine Policy" tidak efektif? Jawaban terhadap pertanyaan tersebut akan dijawab dengan menganalisis kebijakan Korea Selatan terhadap Korea Utara dan respon Korea Utara terhadap "sunshine policy" Korea Selatan serta pengaruh aktor internasional lain terhadap Semenanjung Korea. Bagian selanjutnya merupakan kerangka analisis mengenai CBMs serta 
pembahasan berupa analisis yang dilakukan berdasarkan konsep CBMs dan ditutup dengan kesimpulan.

\section{Kerangka Pemikiran}

\section{Confidence Building Measures}

Konsep Confidence Building Measures (CBMs) pertama muncul pada Januari 1973 di Helsinki dalam pertemuan persiapan untuk merealisasikan agenda Conference on Security and Cooperation in Europe (CSCE) (Fukushima, 2000). CBMs merupakan tindakan yang dilakukan untuk mengurangi ketegangan, menyamakan perspektif serta mendorong kerja sama dalam menyelesaikan konflik keamanan antar aktor-aktor. CBMs dapat diterapkan dalam 4 bidang yaitu, bidang politik, bidang keamanan, bidang ekonomi dan lingkungan hidup, serta dalam bidang Sosial, kemanusian, dan budaya. Tujuan utama penggunaan CBMs dalam bidang politik adalah untuk menyelesaikan suatu konflik melalui solusi yang bersifat politis dan meningkatkan interaksi antar 2 aktor. CBMs dalam bidang politik dapat dilakukan dengan cara para aktor yang berkonflik menghadiri suatu acara bersama, saling mengunjungi negara aktor yang sedang berkonflik (Mason \&

Siegfried, 2013) dan pemasangan hotline antar negara untuk memudahkan komunikasi (Benjamin \& Singh, 1999).

CBMs dalam bidang keamanan digunakan untuk menghindari terjadinya konflik yang diakibatkan oleh perbedaan persepsi atau informasi. Pada umumnya CBMs dalam bidang keamanan dapat dilakukan dengan pertukaran informasi atau personel militer, pembentukan zona demiliterisasi serta dengan memberikan prior notifications sebelum melakukan kegiatan militer. CBMs dalam bidang ekonomi dan lingkungan hidup serta dalam bidang sosial, kemanusiaan dan budaya dapat dilakukan dengan membentuk proyek ekonomi bersama yang lintas batas negara dan membuat pertemuan antar anggota keluarga yang terpisah oleh batas negara. (Mason \& Siegfried, 2013) Upaya CBMs dapat berjalan efektif jika dilakukan secara kontinu, bertahap dan berkelanjutan melalui partisipasi aktif dari aktor-aktor yang terlibat dalam konflik (Department of Political and Security Council Affairs UNC, 1982). 
Higgins dalam tulisannya berpendapat bahwa konsep CBMs memiliki beberapa pendekatan namun secara umum terdapat 4 pendekatan utama, yaitu komunikasi, constraint, transparansi, dan verifikasi (Higgins, 2004). Empat pendekatan tersebut seringkali digunakan dalam CBMs yang diterapkan dalam bidang keamanan. Pendekatan pertama yaitu komunikasi dilakukan antar aktor-aktor yang terlibat dalam konflik untuk meredakan ketegangan. Komunikasi dapat dilakukan dengan pemasangan hotline yang menghubungkan para aktor.

Selanjutnya pendekatan constraint bertujuan untuk memberikan jarak antara pasukan militer dari para aktor yang berkonflik. Constraint dapat dilakukan dengan mengurangi jumlah pasukan dan membatasi senjata yang dapat digunakan di daerah perbatasan para aktor. Sedangkan pendekatan transparansi bertujuan untuk menciptakan keterbukaan terhadap kapabilitas dan aktivitas militer dengan cara pertukaran data dan memberikan pre notification untuk aktivitas militer yang akan dilakukan. Terakhir pendekatan verifikasi bertujuan untuk memastikan komitmen para aktor dengan pembuatan perjanjian yang berisi persetujuan untuk melakukan inspeksi terhadap zona-zona tertentu yang dapat dilakukan oleh pihak ketiga, salah satu pihak maupun bersama-sama (Higgins, 2004).

CBMs dapat diterapkan secara efektif jika para aktor yang berkonflik memiliki political will untuk mencapai tujuannya melalui CBMs. Political will didefinisikan sebagai determinasi para aktor untuk melakukan dan/atau menyatakan suatu hal untuk mencapai tujuan yang diinginkan (Pemerintah Britania Raya, 2004). Political will juga didefinisikan sebagai komitmen dan dukungan antara para pembuat kebijakan untuk membuat kebijakan tertentu sebagai solusi terhadap suatu permasalahan (Post et al., 2010). Sehingga tanpa adanya political will dari para aktor, upaya CBMs tidak dapat berjalan secara efektif dalam mencapai tujuan yang diharapkan (Mason \& Siegfried, 2013). Faktor lain yang dapat mempengaruhi upaya CBMs adalah pengaruh dari pihak ketiga. Implementasi CBMs yang melibatkan pihak ketiga akan dipengaruhi oleh kesesuaian kebijakan luar negeri dan tindakan pihak ketiga terhadap CBMs tersebut (Higgins, 2004).

Melalui penjelasan diatas, terdapat beberapa alasan mengapa konsep CBMs relevan dalam menganalisis ketidakefektifan "Sunshine Policy" Korea Selatan dalam mengatasi ketegangan di Semenanjung Korea. Pertama, konsep CBMs dapat 
menjelaskan tahap-tahap yang terdapat dalam "Sunshine Policy" Korea Selatan serta menjelaskan kesesuaian "Sunshine Policy" Korea Selatan jika dibandingkan dengan konsep CBMs. Kedua, konsep tersebut dapat menjelaskan pengaruh keterlibatan pihak ketiga yaitu Amerika terhadap pelaksanaan "Sunshine Policy". Ketiga, konsep diatas dapat digunakan untuk menjelaskan political will Korea Utara terhadap implementasi CBMs Korea Selatan melalui "Sunshine Policy" dalam ketegangan Semenanjung Korea.

\section{PEMBAHASAN}

Tulisan ini akan menggunakan 4 variabel/bentuk Confidence Building Measures (CBMs) yaitu, CBMs Sosial, Kemanusiaan, dan Budaya, CBMs Ekonomi, CBMs Politik dan CBMs Keamanan. Sehingga tulisan ini akan membahas mengenai 4 bentuk CBMs tersebut yang diterapkan oleh Korea Selatan terhadap Korea Utara dan menganalisa mengenai political will Korea Utara terhadap CBMs Korea Selatan serta pengaruh yang diberikan oleh Amerika terhadap upaya CBMs Korea Selatan.

\section{CONFIDENCE BUILDING MEASURES DALAM SOSIAL, KEMANUSIAAN DAN BUDAYA (CBMS SKB)}

CBMs Sosial, Kemanusiaan dan Budaya merupakan bentuk CBMs yang berjalan tanpa pengaruh dari Amerika dan mendapat reaksi positif oleh Korea Utara. CBMs SKB pada umumnya dijalankan dalam 2 kegiatan, yaitu reuni keluarga Korea yang terpisah saat perang Korea dan bantuan dana serta bantuan kemanusiaan.

Tabel 1 : Reuni keluarga terpisah Korea sejak tahun 2000-2007

\begin{tabular}{|c|c|c|c|c|c|}
\hline Tahun & $\begin{array}{c}\text { Pengecekan } \\
\text { anggota } \\
\text { keluarga }\end{array}$ & $\begin{array}{c}\text { Pertemuan di } \\
\text { Korea Utara }\end{array}$ & $\begin{array}{c}\text { Pertemuan di } \\
\text { Korea Selatan }\end{array}$ & $\begin{array}{c}\text { Jumlah } \\
\text { Pertemuan }\end{array}$ & $\begin{array}{c}\text { Tanggal } \\
\text { Pertemuan }\end{array}$ \\
\hline 2000 & 7.700 Orang & 450 Orang & 1.501 Orang & 2 & 15 Agustus \\
\hline 2001 & 2.670 Orang & 343 Orang & 899 Orang & 1 & 26 Februari \\
\hline 2002 & & & & & 28 April \\
\hline
\end{tabular}




\begin{tabular}{|c|c|c|c|c|c|}
\hline & 1.635 Orang & 1.724 Orang & & 2 & $\begin{array}{c}13 \\
\text { September }\end{array}$ \\
\hline \multirow{4}{*}{2003} & \multirow{4}{*}{ 7.091 Orang } & \multirow{4}{*}{2.691 Orang } & & \multirow{4}{*}{3} & 20 Februari \\
\hline & & & & & 27 Juni \\
\hline & & & & & 20 \\
\hline & & & & & September \\
\hline \multirow[t]{2}{*}{2004} & \multirow[t]{2}{*}{5.007 Orang } & \multirow[t]{2}{*}{1.926 Orang } & & \multirow[t]{2}{*}{2} & 29 Maret \\
\hline & & & & & $11 \mathrm{Juli}$ \\
\hline \multirow[b]{2}{*}{2005} & \multirow[b]{2}{*}{6.957 Orang } & \multirow[b]{2}{*}{1.811 Orang } & & \multirow[b]{2}{*}{2} & 26 Agustus \\
\hline & & & & & 5 November \\
\hline \multirow[t]{2}{*}{2006} & \multirow[t]{2}{*}{8.314 Orang } & \multirow[t]{2}{*}{2.683 Orang } & & \multirow[t]{2}{*}{2} & 20 Maret \\
\hline & & & & & 19 Juni \\
\hline \multirow[t]{2}{*}{2007} & \multirow[t]{2}{*}{9.121 Orang } & \multirow[t]{2}{*}{1.741 Orang } & & \multirow[t]{2}{*}{2} & $9 \mathrm{Mei}$ \\
\hline & & & & & 17 Oktober \\
\hline \multirow[t]{2}{*}{ Total } & 48.495 & \multirow[t]{2}{*}{13.369 Orang } & 2.400 Orang & \multirow[t]{2}{*}{16} & \\
\hline & Orang & & & & \\
\hline
\end{tabular}

Sumber : Kementerian Unifikasi Korea Selatan

Data diatas menunjukkan pengecekan status hidup atau mati anggota keluarga Korea yang terpisah dari periode 2000-2007 dan jumlah pertemuan serta jumlah orang yang menghadiri reuni keluarga terpisah Korea sejak tahun 2000 sampai 2007. Reuni keluarga terpisah Korea merupakan salah satu agenda utama Korea Selatan dalam menerapkan CBMs. Terjadinya Reuni keluarga terpisah Korea merupakan salah satu pencapaian terbesar dari Inter-Korean Summit pada tahun 2000. Inter-Korean Summit menghasilkan North-South Joint Declaration pada tanggal 15 Juni 2000 yang berisi mengenai pelaksanaan reuni keluarga terpisah Korea pada Agustus 2002. Reuni keluarga terpisah Korea dilaksanakan secara terus menerus tanpa berhenti sampai akhir masa pemerintahan Roh Moo Hyun.

Pemerintah Korea Selatan dan Korea Utara selama periode tahun 2000-2007 telah melakukan pengecekan status hidup mati terhadap lebih dari 40.795 anggota keluarga Korea yang terpisah. Sejak pertama kali dilaksanakan pada tahun 2000, reuni keluarga terpisah Korea telah dilaksanakan sebanyak 16 kali sampai tahun 
2007. Dalam 16 pertemuan tersebut telah terjadi pertemuan antara 15.769 orang. Reuni tersebut juga telah dilaksanakan minimal 2 kali per tahun kecuali pada tahun 2001 serta jumlah anggota keluarga yang mengikuti reuni tersebut per tahun juga tidak mengalami penurunan yang signifikan dan berlanjut cukup stabil. 2003 menjadi tahun dengan jumlah pertemuan terbanyak yaitu 3 reuni dalam 1 tahun yang diikuti oleh 2.691 orang dalam 3 pertemuan tersebut.

Keunikan dari reuni keluarga terpisah Korea sebagai salah satu upaya CBMs SKB Korea Selatan adalah terlaksananya kegiatan tersebut tidak tergantung pada situasi politik, keamanan maupun pengaruh dari pihak ketiga yaitu Amerika. Salah satu contohnya adalah Pertempuran Kedua Yeonpyeong antara Korea Selatan dan Korea Utara di perairan Pulau Yeonpyeong yang menghasilkan total 19 korban jiwa dari kedua negara pada 29 Juni 2002 (Encyclopedia of Korean Culture, 2009) tidak menyebabkan batalnya reuni keluarga terpisah Korea pada 13 September 2002.

Selain Reuni keluarga terpisah Korea, Korea Selatan juga memberikan bantuan kemanusiaan kepada Korea Utara dalam bentuk bantuan gratis maupun bantuan pangan dalam bentuk pinjaman. Bantuan tersebut dilaksanakan dengan tujuan untuk menjamin keselamatan warga-warga Korea Utara serta memperkuat identitas bangsa Korea antara Korea Selatan dan Utara (Kementerian Unifikasi Korea Selatan).

Tabel 2 : Bantuan dana Korea Selatan kepada Korea Utara (Unit : Miliar WON Korea Selatan)

\begin{tabular}{|c|c|c|c|}
\hline Tahun & Bantuan Gratis & $\begin{array}{c}\text { Bantuan Pangan dalam } \\
\text { Bentuk Pinjaman }\end{array}$ & Total \\
\hline 1998 & 15,4 & & 15,4 \\
\hline 1999 & 33,9 & & 33,9 \\
\hline 2000 & 94,4 & 105,7 & 200,1 \\
\hline 2001 & 91,3 & & 91,3 \\
\hline 2002 & 107,5 & 151 & 258,5 \\
\hline 2003 & 101,6 & 151 & 252,6 \\
\hline 2004 & 121,1 & 135,9 & 257 \\
\hline
\end{tabular}




\begin{tabular}{|c|c|c|c|}
\hline 2005 & 124 & 178,7 & 302,7 \\
\hline 2006 & 213,9 & & 213,9 \\
\hline 2007 & 176,7 & 150,5 & 327,2 \\
\hline Total $:$ & 1.798 & 872,8 & $2.670,8$ \\
\hline
\end{tabular}

Sumber : Kementerian Unifikasi Korea Selatan

Tabel diatas menunjukkan selama 10 tahun Korea Selatan telah memberikan total bantuan yang bernilai 2670.8 miliar WON kepada Korea Utara yang terbagi dalam 2 bentuk yaitu bantuan gratis dan bantuan pangan dengan bentuk pinjaman. Bantuan gratis Korea Selatan terhadap Korea Utara dilaksanakan setiap tahun dan mengalami peningkatan yang stabil dengan penurunan yang tidak signifikan. Bantuan gratis yang dilakukan sejak tahun 1998 sampai 2007 mencapai total nilai 1798 miliar WON. Sedangkan bantuan pangan dilakukan pada tahun saat Korea Utara sedang mengalami krisis pangan. Nilai bantuan pangan yang dilakukan pada periode 1998 sampai 2007 mencapai 872.8 miliar WON.

Sama halnya dengan reuni keluarga terpisah Korea, bantuan kemanusiaan diatas tidak terhambat meski adanya konflik dalam bidang keamanan maupun politik antara Korea Selatan dan Korea Utara. Tetapi bantuan kemanusiaan yang dilakukan secara terus menerus oleh Korea Selatan mendapat kritik dari Amerika yang menganggap bantuan tersebut tidak menghasilkan perubahan dalam Korea Utara (Ryu, 2009). Meski adanya kritik dari Amerika, bantuan kemanusiaan tetap berjalan tanpa berhenti.

Dengan CBMs SKB yang dilakukan melalui reuni keluarga terpisah Korea dan Bantuan kemanusiaan, Korea Selatan menghasilkan rasa aman dan kepercayaan antara warga negara dari kedua Korea. Kepercayaan yang terbangun di antara kedua warga negara Korea tersebut melalui CBMs SKB mendorong dan mempengaruhi implementasi CBMs Ekonomi yang dilakukan oleh Korea Selatan.

\section{CONFIDENCE BUILDING MEASURES DALAM EKONOMI (CBMS EKONOMI)}

Korea Selatan telah menerapkan berbagai kerja sama ekonomi dengan Korea Utara dalam upaya penerapan CBMs Ekonomi. Dari berbagai kerja sama tersebut terdapat 3 kerja sama utama yaitu, pariwisata Kumgang-San, pendirian kawasan industri di KaeSong dan meningkatkan kegiatan ekspor-impor Inter-Korea. Kerja 
sama ekonomi diatas diawali saat mantan direktur Hyundai, Chung Ju Yung dikirim ke Korea Utara untuk mendiskusikan pelaksanaan pariwisata Kumgang -San. Pertemuan tersebut terjadi pada bulan Juni 1998 dan dilanjutkan pada bulan Oktober 1998. Dalam pertemuan kedua, pemerintah Korea Selatan melalui Hyundai menyepakati pelaksanaan pariwisata Kumgang-San yang pertama pada bulan November 1998 (금강산, 2019).

Pada tahun berikutnya Hyundai membentuk anak perusahaan yang dinamai Hyundai Asan yang khusus bekerja di bidang pariwisata Kumgang-San. Pada awalnya pariwisata Kumgang-San hanya diizinkan bagi warga negara Korea Selatan dengan menggunakan jalur laut dari pelabuhan Donghae. Hal tersebut mengalami perubahan pada tahun 2000, dimana warga negara asing termasuk warga negara Jepang dapat mengikuti pariwisata Kumgang-San melalui Hyundai Asan. Pada September 2003, Korea Utara mengizinkan peserta pariwisata Kumgang-San memasuki Korea Utara menggunakan jalur darat dari daerah Kangwon, Korea Selatan. Penggunaan jalur darat bagi peserta pariwisata Kumgang-San merupakan pertama kalinya warga sipil Korea Selatan memasuki wilayah Korea Utara melewati Garis Demarkasi Militer.

Tabel 3 : Jumlah peserta pariwisata Kumgang-San

\begin{tabular}{|c|c|c|c|}
\hline Tahun & Jalur Laut & Jalur Darat & Total \\
\hline $1998-2000$ & 371.637 Orang & & 371.637 Orang \\
\hline 2001 & 57.879 Orang & & 57.879 Orang \\
\hline 2002 & 84.727 Orang & & 84.727 Orang \\
\hline 2003 & 38.306 Orang & 36.028 Orang & 74.334 Orang \\
\hline 2004 & 449 Orang & 267.971 Orang & 268.420 Orang \\
\hline 2005 & & 298.247 Orang & 298.247 Orang \\
\hline 2006 & & 234.446 Orang & 234.446 Orang \\
\hline 2007 & & 345.006 Orang & 345.006 Orang \\
\hline Total & 552.998 Orang & 1.181.698 Orang & 1.734.696 Orang \\
\hline
\end{tabular}

Sumber : Kementerian Unifikasi Korea Selatan 
Melalui pariwisata tersebut, mendorong terjadinya berbagai kerja sama ekonomi lain antara Korea Selatan dan Korea Utara. Pariwisata Kumgang-San juga tetap Sejak pertama kali dilaksanakan pariwisata Kumgang-San mengalami peningkatan setiap tahun. Pariwisata Kumgang-San tidak hanya menghasilkan Korea Utara yang lebih terbuka kepada masyarakat Korea Selatan tetapi kepada masyarakat internasional. berjalan meski terjadi ketegangan antara Korea Selatan dan Korea Utara dalam bidang keamanan.

Salah satu contohnya adalah uji coba nuklir pertama Korea Utara pada tahun 2006 tidak mengakibatkan berhentinya pariwisata Kumgang-San (금강산, 2019). Hal tersebut menunjukkan adanya perpisahan dalam CBMs Ekonomi Korea Selatan dengan CBMs pada bidang keamanan dan politik. Pada periode 1998-2007 terdapat total 1.734.696 peserta yang mengikuti pariwisata Kumgang-San melalui jalur laut maupun jalur darat. Selain pariwisata Kumgan-San, pendirian kawasan industri di KaeSong merupakan salah satu hasil utama dari CBMs ekonomi Korea Selatan.

Kesepakatan untuk mendirikan kawasan industri di KaeSong, Korea Utara tercapai pada Agustus tahun 2000. Sejak kesepakatan tersebut dibutuhkan 5 tahun untuk perusahaan Korea Selatan secara resmi menjalankan usahanya di wilayah KaeSong, yaitu pada September tahun 2005. Selama 5 tahun tersebut Korea Utara menetapkan regulasi mengenai kawasan industri Kaesong serta menyepakati sarana komunikasi, prosedur operasi dan pengawasan di kawasan industri KaeSong. Selain itu Korea Selatan dan Korea Utara juga menyepakati mengenai izin masuk dan tinggal bagi pekerja-pekerja Korea Selatan di wilayah KaeSong (Kementerian Unifikasi Korea Selatan).

Tabel 4 : Data Kawasan Industri KaeSong

(Unit : Juta Dolar US)

\begin{tabular}{|c|c|c|c|c|}
\hline Tahun & $\begin{array}{c}\text { Jumlah } \\
\text { Perusahaan } \\
\text { Korea Selatan }\end{array}$ & $\begin{array}{c}\text { Jumlah } \\
\text { Pekerja } \\
\text { Korea Selatan }\end{array}$ & $\begin{array}{c}\text { Jumlah } \\
\text { Pekerja } \\
\text { Korea Utara }\end{array}$ & $\begin{array}{c}\text { Nilai } \\
\text { Produksi }\end{array}$ \\
\hline 2005 & 18 & 507 Orang & 6.013 Orang & 14,91 \\
\hline 2006 & 30 & 791 Orang & 11.160 Orang & 73,73 \\
\hline 2007 & 65 & 785 Orang & 22.538 Orang & 184,78 \\
\hline
\end{tabular}

Sumber : Kementerian Unifikasi Korea Selatan 
Data diatas menunjukkan jumlah perusahaan Korea Selatan di kawasan industri KaeSong serta jumlah pekerja Korea Selatan dan Korea Utara di perusahaan-perusahaan tersebut. Nilai produksi yang dihasilkan dari kawasan industri KaeSong juga meningkat secara signifikan setiap tahunnya. Dalam periode 2005-2007 total nilai produksi yang dihasilkan dari kawasan industri KaeSong mencapai 273 Juta Dolar US. Peningkatan jumlah perusahaan Korea Selatan yang awalnya hanya 18 perusahaan menjadi 65 dan jumlah pekerja Korea Utara yang bertambah 16.000 pekerja sejak tahun pertama kawasan industri KaeSong beroperasi menunjukkan adanya rasa percaya dari perusahaan-perusahaan Korea Selatan terhadap Korea Utara sebagai kawasan industri yang baru.

Tabel 5 : Jumlah Kegiatan Ekspor-Impor Inter-Korea

\begin{tabular}{|c|c|c|c|}
\hline Tahun & $\begin{array}{c}\text { Jumlah } \\
\text { Kegiatan Ekspor }\end{array}$ & $\begin{array}{c}\text { Jumlah } \\
\text { Kegiatan Impor }\end{array}$ & Total \\
\hline $1989-2002$ & 22.732 & 25.268 & 48.000 \\
\hline 2003 & 4.853 & 6.356 & 11.209 \\
\hline 2004 & 6.953 & 5.940 & 12.893 \\
\hline 2005 & 11.828 & 9.337 & 21.165 \\
\hline 2006 & 17.039 & 16.412 & 33.451 \\
\hline 2007 & 26.731 & 25.027 & 51.758 \\
\hline
\end{tabular}

Sumber : Kementerian Unifikasi Korea Selatan

*Data diatas merupakan perspektif dari Korea Selatan

Selain jumlah perusahaan dan jumlah pekerja yang bertambah di kawasan industri KaeSong, kegiatan ekspor-impor Inter-Korea juga mengalami peningkatan setiap tahunnya. Menurut data diatas, kegiatan ekspor-impor yang hanya mencapai 11.209 kegiatan di tahun 2003 meningkat secara stabil di tahun-tahun setelahnya dan pada tahun 2007 kegiatan ekspor-impor Inter-Korea mencapai angka 51.758. Semakin meningkatnya kegiatan ekspor-impor Inter-Korea, jenis barang yang diperdagangkan antara Korea Selatan dan Korea Utara juga mengalami peningkatan. 
Tabel 6 : Jumlah Jenis Barang Dalam Kegiatan Ekspor-Impor Inter-Korea

\begin{tabular}{|c|c|c|c|}
\hline Tahun & $\begin{array}{c}\text { Jumlah Jenis } \\
\text { Barang Ekspor }\end{array}$ & $\begin{array}{c}\text { Jumlah Jenis } \\
\text { Barang Impor }\end{array}$ & Total \\
\hline $1989-2002$ & 1.254 & 585 & 1.394 \\
\hline 2003 & 530 & 186 & 588 \\
\hline 2004 & 575 & 202 & 634 \\
\hline 2005 & 712 & 381 & 775 \\
\hline 2006 & 697 & 421 & 757 \\
\hline 2007 & 803 & 450 & 853 \\
\hline
\end{tabular}

Sumber : Kementerian Unifikasi Korea Selatan

*Data diatas merupakan perspektif dari Korea Selatan

**Jumlah total berbeda dengan angka melalui penambahan per tahun karena terdapat jenis barang yang sama dalam ekspor-impor

Data diatas menunjukkan jumlah jenis barang yang diekspor oleh Korea Selatan ke Korea Utara dan jumlah jenis barang yang diimpor oleh Korea Selatan dari Korea Utara. Jumlah barang yang diekspor oleh Korea Selatan ke Korea Utara mengalami penambahan tahun ke tahun dengan penurunan yang minim. Sedangkan jumlah barang yang diimpor oleh Korea selatan dari Korea Utara mengalami peningkatan yang konsisten dari tahun ke tahun. Pada tahun 2007 jumlah barang yang diperdagangkan antara Korea Selatan dan Korea Utara mencapai 853 jenis barang yang berbeda. Seiring berjalannya kerja sama ekonomi Inter-Korea, jenis barang yang diperdagangkan juga semakin meningkat dan bervariasi.

Tabel 7 : Nilai Barang Dalam Kegiatan Ekspor-Impor Inter-Korea

(Unit : Juta Dollar US)

\begin{tabular}{|c|c|c|c|}
\hline Tahun & $\begin{array}{c}\text { Nilai Barang } \\
\text { Ekspor }\end{array}$ & $\begin{array}{c}\text { Nilai Barang } \\
\text { Impor }\end{array}$ & Total \\
\hline $1989-1999$ & 636 & 1.466 & 2,102 \\
\hline
\end{tabular}




\begin{tabular}{|c|c|c|c|}
\hline 2000 & 273 & 152 & 425 \\
\hline 2001 & 227 & 176 & 403 \\
\hline 2002 & 370 & 272 & 642 \\
\hline 2003 & 435 & 289 & 724 \\
\hline 2004 & 439 & 258 & 697 \\
\hline 2005 & 715 & 340 & 1.055 \\
\hline 2006 & 830 & 520 & 1.350 \\
\hline 2007 & 1,023 & 765 & 1.798 \\
\hline Total & 4.957 & 4.238 & 9.196 \\
\hline
\end{tabular}

Sumber : Kementerian Unifikasi Korea Selatan

*Data diatas merupakan perspektif dari Korea Selatan

Dengan meningkatnya frekuensi kegiatan ekspor-impor dan jumlah jenis barang yang diperdagangkan dalam ekspor-impor Inter-Korea, nilai barang yang dalam kegiatan ekspor-impor juga mengalami peningkatan. Nilai barang yang diekspor oleh Korea Selatan ke Korea Utara mengalami peningkatan setiap tahun begitu juga dengan nilai barang yang diimpor oleh Korea Selatan dari Korea Utara. Sejak penerapan "sunshine policy" sebagai upaya CBMs pada akhir tahun 1999 sampai 2007, nilai barang yang diperdagangkan antara Korea Selatan dan Korea Utara mencapai 7,094 miliar Dolar US. Hal tersebut jauh lebih tinggi jika dibandingkan dengan 10 tahun sebelum penerapan "sunshine policy", dimana nilai barang yang diperdagangkan dalam ekspor-impor Inter-Korea hanya mencapai 2,102 miliar Dolar US.

Melalui CBMs Ekonomi, Korea Selatan meningkatkan kerja sama ekonomi dengan Korea Utara. CBMs Ekonomi Korea Selatan juga membuat Korea Utara yang lebih terbuka terhadap dunia internasional dengan mengadakan pariwisata Kumgang-San yang bisa diikuti oleh warga negara Korea Selatan maupun warga negara asing lain seperti Jepang. Selain itu dengan mendirikan kawasan industri KaeSong, Korea Selatan berhasil menempatkan perusahaan negaranya di wilayah Korea Utara serta meningkatkan pertukaran barang antara Korea Selatan dan Korea Utara. Korea Selatan juga melalui kerja sama ekonomi mempererat hubungannya dengan Korea Utara, meski masih di bawah kerja sama dan bantuan 
ekonomi yang telah dilakukan oleh Cina terhadap Korea Utara khususnya pasca meninggalnya Kim Il Sung pada tahun 1994 (Miryanti \& Pridarita, 2020).

\section{CONFIDENCE BUILDING MEASURES DALAM POLITIK (CBMS POLITIK)}

Salah satu pencapaian terbesar pemerintah Kim Dae Jung, khususnya dalam CBMs politik adalah merealisasikan Inter-Korean Summit Pertama antara pemimpin kedua Korea pada 13 Juni 2000. Hal tersebut dicapai oleh Kim Dae Jung setelah 2 tahun menjabat sebagai presiden Korea Selatan. Untuk merealisasikan Inter-Korean Summit Pertama, Pemerintah Kim Dae Jung melakukan berbagai pertemuan formal maupun non-formal dengan pemerintah Korea Utara sejak tahun 1998. Pertemuan-pertemuan persiapan tersebut awalnya dilaksanakan di Tiongkok dan berpindah ke Panmunjom yang merupakan Area Keamanan Bersama Korea.

Inter-Korean Summit Pertama menjadi titik balik bagi hubungan Korea Selatan dan Korea Utara. Inter-Korean Summit Pertama menghasilkan June 15th North-South Joint Declaration yang berisi mengenai keinginan untuk menyelesaikan perang dan pilar-pilar untuk menuju reunifikasi melalui dialog. Inter-Korean Summit Pertama memudahkan pelaksanaan CBMs dalam berbagai bidang lain, seperti upaya meningkatkan kerja sama ekonomi antara Korea Selatan dan Korea Utara serta pelaksanaan reuni keluarga terpisah Korea. Inter-Korea Summit yang Pertama juga menjadi awal dari pertemuan tingkat Menteri antara Korea Selatan dan Korea Utara yang Pertama (Kementerian Unifikasi Korea Selatan).

Pada tahun yang sama dengan pelaksanaan Inter-Korea Summit, dilaksanakan Inter-Korean Ministerial Meeting Pertama pada 29 Juli 2000. Melalui Inter-Korean Ministerial Meeting yang Pertama, Korea Selatan dan Korea Utara menyetujui untuk menghilangkan kecurigaan dan konflik antara kedua Korea serta meningkatkan kepercayaan dan kerja sama untuk menyelesaikan berbagai masalah. Inter-Korean Ministerial Meeting Pertama juga secara konkret menyetujui untuk menjalankan kembali Inter-Korean Liaison Office mulai dari tanggal 15 Agustus 2000. Dengan menjalankan kembali Inter-Korean Liaison Office yang terletak di Panmunjom, diharapkan dapat meningkatkan komunikasi antara Korea Selatan dan Korea Utara (Kementerian Unifikasi Korea Selatan).

Inter-Korean Ministerial Meeting Pertama juga menyetujui untuk mengadakan Inter-Korean Ministerial Meeting Kedua pada 29 Agustus 2000. Pada tahun 2000 
sendiri terjadi total 4 Inter-Korean Ministerial Meeting. Sejak pertama kali dilaksanakan pada 29 Juli 2000, Inter-Korean Ministerial Meeting dilaksanakan setiap tahun sampai tahun 2007. Selama periode 2000-2007 telah dilaksanakan 21 Inter-Korean Ministerial Meeting.

Tabel 8 : Jumlah Pertemuan Korea Selatan dan Korea Utara Dalam Bidang Politik

\begin{tabular}{|c|c|c|c|c|c|c|c|c|c|c|c|}
\hline Tahun & 1998 & 1999 & 2000 & 2001 & 2002 & 2003 & 2004 & 2005 & 2006 & 2007 & Total \\
\hline $\begin{array}{c}\text { Jumlah } \\
\text { pertemuan }\end{array}$ & 4 & 8 & 18 & 2 & 4 & 5 & 2 & 10 & 5 & 13 & 71 \\
\hline
\end{tabular}

Sumber : Kementerian Unifikasi Korea Selatan

Selain Inter-Korean Ministerial Meeting, terdapat berbagai pertemuan dalam bidang politik antara pemerintah Korea Selatan dan Korea Utara yang mencakup Inter-Korean Summit Kedua dan Inter-Korean Prime Minister Meeting pada masa pemerintahan Roh Moo Hyun. Data diatas menunjukan selama periode 1998-2007 terjadi 71 pertemuan antara Korea Selatan dan Korea Utara dalam bidang politik. Pada tanggal 2 Oktober 2007, presiden Korea Selatan saat itu Roh Moo Hyun, melewati Military Demarcation Line Korea untuk menghadiri Inter-Korean Summit Kedua dengan berjalan kaki. Roh Moo Hyun menjadi presiden Korea Selatan pertama yang melewati Military Demarcation Line Korea menggunakan jalur darat.

Dalam Inter-Korean Summit Kedua, pemerintahan Korea Selatan dan Korea Utara membahas mengenai upaya pengurangan ketegangan dan peningkatan kepercayaan dalam bidang keamanan melalui Inter-Korean Defence Minister Meeting dan upaya denuklirisasi di Korea Utara serta pelaksanaan Inter-Korean Prime Minister Meeting pada bulan November 2007 di Korea Selatan. Meski berbagai pertemuan telah dilaksanakan secara berlanjut setiap tahun, hubungan politik antara Korea Selatan dan Korea Utara mendapat berbagai permasalahan.

Korea Utara melakukan berbagai penghinaan terhadap beberapa politisi Korea Selatan dan melakukan berbagai propaganda saat pertemuan Reuni Keluarga Terpisah Korea. Korea Selatan meminta Korea Utara untuk berhenti melakukan tindakan-tindakan diatas dan mengingatkan tindakan-tindakan tersebut akan menghambat proses rekonsiliasi antara Korea Selatan dan Korea Utara. Hubungan 
aliansi antara Korea Selatan dan Amerika Serikat juga menjadi salah satu hambatan dalam hubungan Inter-Korean. Setelah Inter-Korean Summit Pertama, Korea Utara menyatakan slogan “Uriminzokkiri” (우리민족끼리) yang berisi keinginan untuk menyelesaikan permasalahan dalam hubungan Inter-Korea oleh bangsa Korea itu sendiri tanpa pengaruh dan ikut campur dari negara lain (우리 민족끼리, 2007).

Keinginan Korea Utara di atas sulit untuk dijalankan oleh Korea Selatan yang memiliki hubungan aliansi yang erat dengan Amerika Serikat. Salah satu contohnya adalah saat Perang Irak, dimana Korea Selatan mengirim pasukan atas permintaan Amerika Serikat. Hal tersebut mendapat kritikan besar dari Korea Utara yang menganggap tindakan Amerika dan Korea Selatan melanggar kedaulatan negara lain. Hard-line policy yang diterapkan oleh pemerintahan George W. Bush sejak tahun 2001 terhadap Korea Utara juga mengganggu upaya CBMs Korea Selatan. Selain hard-line policy, pemerintahan George W. Bush juga melakukan berbagai tuduhan terhadap Korea Utara. Tuduhan tersebut meliputi pencetakan Dolar Amerika palsu (Mihm, 2006) oleh Korea Utara serta pencucian uang yang dilakukan oleh Korea Utara melalui bank yang terletak di Makau (Laundering charge, 2005). Tuduhan-tuduhan tersebut memperburuk hubungan antara Amerika dan Korea Utara serta memberi pengaruh negatif terhadap hubungan Korea Selatan dan Korea Utara.

CBMs dalam bidang politik yang dilakukan oleh Korea Selatan menghasilkan berbagai pencapaian dalam hubungan Inter-Korea. Pencapaian tersebut meliputi Inter-Korean Summit antara pemimpin kedua Korea serta pelaksanaan Inter-Korean Ministerial Meeting yang meningkatkan komunikasi antara pemerintah Korea Selatan dan Korea Utara. Namun upaya CBMs Korea Selatan dalam bidang politik mendapat pengaruh yang besar dari Amerika. Hard-line policy Amerika dan status Korea Selatan sebagai negara sekutu Amerika memberikan pengaruh negatif pada hubungan Inter-Korea.

\section{CONFIDENCE BUILDING MEASURES DALAM KEAMANAN (CBMS KEAMANAN)}

Keamanan menjadi bidang yang sangat sensitif dalam hubungan Korea Selatan dan Korea Utara sehingga penerapan CBMs keamanan menjadi tidak 
mudah. Sampai saat ini Perang Korea yang terjadi pada 25 Juni 1950 belum dinyatakan berakhir sebab para pihak hanya menyepakati gencatan senjata pada 27 Juli 1953. Pemerintah Korea Selatan pada masa Kim Dae Jung dan Roh Moo Hyun telah menjadikan bidang keamanan sebagai fokus utama dan telah melakukan berbagai upaya untuk menerapkan CBMs keamanan. Penerapan CBMs keamanan menjadi penting bagi Korea Selatan, sebab anggaran pertahanan Korea Selatan masih berada di bawah negara-negara lain di Asia Timur seperti Jepang dan Cina (Saeputra, 2019).

Tabel 8 : Jumlah Pertemuan Korea Selatan dan Korea Utara Dalam Bidang Keamanan

\begin{tabular}{|c|c|c|c|c|c|c|c|c|c|}
\hline Tahun & 2000 & 2001 & 2002 & 2003 & 2004 & 2005 & 2006 & 2007 & Total \\
\hline $\begin{array}{c}\text { Jumlah } \\
\text { Pertemuan }\end{array}$ & 4 & 2 & 9 & 6 & 5 & 3 & 4 & 11 & 44 \\
\hline
\end{tabular}

Sumber : Kementerian Unifikasi Korea Selatan

Pembicaraan mengenai bidang keamanan antara Korea Selatan dan Korea Utara tidak pernah terjadi sejak gencatan senjata pada 27 Juli 1953. Pembicaraan mengenai bidang keamanan kembali terjadi pada masa pemerintahan Kim Dae Jung. Data diatas menunjukkan telah terjadi 44 pertemuan antara Korea Selatan dan Korea Utara dalam bidang keamanan. Sejak penerapan sunshine policy pada tahun 2000, pertemuan antara Korea Selatan dan Korea Utara dalam bidang keamanan berlanjut tanpa berhenti selama masa pemerintahan Kim Dae Jung dan Roh Moo Hyun. Meski terjadi berbagai pertemuan dan upaya CBMs oleh pihak Korea Selatan, CBMs dalam bidang keamanan tidak berjalan dengan baik.

Pada 15 Juni 1999, terjadi pertempuran YeonPyeong Pertama yang mengakibatkan 7 personel militer Korea Selatan terluka sedangkan jumlah korban dari Korea Utara diperkirakan 30 terluka dan 20 meninggal dunia (Hwang, 1999). Keadaan dalam bidang keamanan mulai membaik pada tahun 2000 saat dilaksanakan pertemuan pertama antara Menteri Pertahanan Korea Selatan dan Korea Utara di pulau Jeju pada 25 September 2000 (Kementerian Unifikasi Korea Selatan). Hubungan Korea Selatan dan Korea Utara kembali memburuk pada tahun 
2002 saat terjadi pertempuran YeonPyeong Kedua pada tanggal 29 Juli. Pertempuran tersebut mengakibatkan 24 korban dari pihak Korea Selatan dan 38 korban dari pihak Korea Utara (Choi, 2015). Pasca pertempuran YeonPyeong Kedua, pemerintahan Kim Dae Jung kembali mengadakan 9 pertemuan dalam bidang keamanan dengan Korea Utara. Pada akhir masa pemerintahan Kim Dae Jung, Korea Utara menarik diri dari Perjanjian Nonproliferasi Nuklir Meski berbagai upaya CBMs telah dilakukan, pemerintahan Kim Dae Jung gagal mencapai hasil yang baik dalam CBMs keamanan.

Hubungan Korea Selatan dan Korea Utara dalam bidang keamanan pada masa pemerintahan Roh Moo Hyun juga tidak mengalami perubahan yang signifikan. Meski pemerintah Korea Selatan mengajak Korea Utara untuk mengurangi ketegangan di wilayah laut barat, Korea Utara terus melakukan berbagai tindakan provokatif terhadap Korea Selatan. Salah satunya adalah kapal-kapal militer Korea Utara yang sering kali memasuki wilayah laut Korea Selatan. Pemerintah Roh Moo Hyun juga melaksanakan Perundingan enam negara pertama pada tahun 2003 yang dihadiri oleh Korea Selatan, Korea Utara, Amerika, Rusia, Tiongkok dan Jepang (Sulaiman, 2020) untuk membahas mengenai program nuklir Korea Utara. Dalam perundingan enam negara tersebut Amerika bersifat tegas dengan menuntut pemberhentian penuh terhadap pengembangan nuklir Korea Utara, sedangkan Korea Selatan menunjukkan sifat yang lebih lunak (Veronica, 2015). Hubungan antara Korea Selatan dan Korea Utara kembali memburuk saat Korea Utara menyatakan bahwa mereka memiliki senjata nuklir pada tanggal 10 Februari 2005 (북, 핵무기제조, 2005).

Menghadapi situasi tersebut, Korea Selatan mendorong terjadinya Perundingan enam negara ke 4 pada tanggal 19 September 2005. Dalam perundingan tersebut disepakati Deklarasi bersama 19 September yang menyatakan penyerahan seluruh senjata nuklir dan pemberhentian seluruh program nuklir oleh Korea Utara. Deklarasi tersebut juga menyatakan komitmen para negara untuk menjaga kedamaian di Semenanjung Korea dan Asia serta hubungan yang saling menghormati (Kementerian Luar Negeri Korea Selatan). Tetapi setelah 1 tahun sejak Deklarasi 19 September, Korea Utara melaksanakan 
uji coba senjata nuklir pertama pada 9 Oktober 2006 yang kembali mengakibatkan ketegangan di Semenanjung Korea (Kementerian Unifikasi Korea Selatan).

Sebagai jawaban untuk pertanyaan penelitian, Upaya CBMs yang dijalankan oleh Korea Selatan pada masa pemerintahan Kim Dae Jung dan Roh Moo hyun terhadap Korea Utara melalui Sunshine Policy berakhir tidak efektif. Meski CBMs dalam bidang sosial, kemanusiaan, dan budaya serta dalam bidang ekonomi menghasilkan hasil yang cukup baik tetapi CBMs dalam bidang politik dan keamanan mengalami kegagalan. Hal tersebut disebabkan pengaruh besar Amerika terhadap politik Korea Selatan dan hubungan kedua negara sebagai negara aliansi. Sedangkan dalam bidang keamanan, Korea Utara tidak menunjukkan political will untuk mencapai tujuan yang diharapkan dari CBMs Korea Selatan, yaitu stabilitas keamanan di Semenanjung Korea. Selama 10 tahun masa kepresidenan Kim Dae Jung dan Roh Moo Hyun, Korea Utara terus melakukan tindakan agresif terhadap Korea Selatan termasuk 2 pertempuran di laut YeonPyeong dan 1 uji coba senjata nuklir.

\section{KESIMPULAN}

Tulisan ini menjelaskan CBMs yang diterapkan oleh Korea Selatan pada masa pemerintahan Kim Dae Jung dan Roh Moo Hyun terhadap Korea Utara. Pelaksanaan CBMs Korea Selatan melalui sunshine policy tidak efektif karena pengaruh pihak ketiga yaitu Amerika terhadap penerapan CBMs politik Korea Selatan. Di sisi lain tidak adanya political will Korea Utara untuk menangkap CBMs Korea Selatan dalam bidang keamanan menjadi alasan utama dari ketidakefektifan CBMs tersebut. Dalam tulisan ini konsep CBMs sebagai kerangka analisis dapat digunakan untuk menganalisis penerapan CBMs suatu negara dalam 4 bidang yaitu Sosial, Kemanusiaan dan Budaya, Ekonomi, Politik dan Keamanan serta 2 faktor yang mempengaruhi penerapan CBMs yaitu political will dari para pihak yang terlibat dan pengaruh pihak ketiga terhadap pelaksanaan CBMs. Tetapi konsep CBMs tersebut tidak mempertimbangkan faktor-faktor lain yang dapat berpengaruh dalam penerapan CBMs. Kajian-kajian pada masa yang akan datang mengenai CBMs Korea Selatan terhadap Korea Utara dapat dilakukan dengan membandingkan 2 atau lebih pemerintahan Korea Selatan yang berbeda dan/atau melakukan analisis menggunakan faktor-faktor pengaruh yang berbeda. 


\section{DAFTAR PUSTAKA}

Beck, Peter M and Reader, Nicholas. (2005) "Facilitating Reform in North Korea: The Role of Regional Actors and NGOs", Asian Perspective, Vol. 29, No. 3, pp. 31-49.

Benjamin L. Self and Ranjeet K. Singh. (1999) "Introduction" in Investigating Confidence-Building Measures in the Asia-Pacific Region, The Henry L. Stimson Center.

Cha, Victor D and Kang, David C. (2004) "The Debate over North Korea", Political Science Quarterly, Vol. 119, No. 2 (Summer), pp. 229-254.

Choi, HyunSoo. (2015, 29 Juni) “[제2 연평해전 13주년] 선제 공격한 北 피해 더 커... ‘패전' $\rightarrow$ ‘승전' 재평가돼야”, Kukmin Ilbo.

Available at:

http:/ / news.kmib.co.kr/article/view.asp?arcid=0923137750\&code $=11122100$ $\& c p=n v$ (Accessed: 8 Juni 2020).

Department of Political and Security Council Affairs United Nations Centre for Disarmament Report of the Secretary-General (1982) Comprehensive Study on Confidence-building Measures (Online). Available at:

https://www.un-ilibrary.org/content/books/9789210585125 (Accessed: 5 Juni 2020).

Encyclopedia of Korean Culture (2020) (Online)

Available at:

http://encykorea.aks.ac.kr/Contents/Item/E0066633 (Accessed: 26 April 2020).

Foley, James A. (2003) “"Sunshine" or Showers for Korea's Divided Families?,” World Affairs, Vol. 165, No. 4 (SPRING), pp. 179-184.

Fukushima, Akiko. (2000) Multilateral Confidence Building Measures in Northeast Asia: Receding or Emerging?", Henry L. Stimson Center, Washington, D.C.

Haggard, Stephan and Noland, Marcus. (2008) "North Korea in 2007: Shuffling in from the Cold", Asian Survey, Vol. 48, No. 1 (January/February), pp. 107-115.

Han, Y. (2002) "The Sunshine Policy and Security on the Korean Peninsula: A Critical Assessment and Prospects". Asian Perspective, Vol. 26, No. 3, pp 37-69. 
Heo, Uk and Chong, MinHyun. (2001) "An Analysis of South Korea's Policy Toward North Korea", Pacific Focus, Vol. 16, No. 1 (Spring), pp. 89-102.

Higgins, Holly. (2004) "Applying Confidence-Building Measures in a Regional Context," ISIS Publications Vol. 21 No. 15.

Hwang, DaeIl. (1999, 3 Juli) “연평해전' 해군장병 7명 특진”, Yonhap News.

Available at:

https: / / news.naver.com $/$ main $/$ read.nhn?mode=LSD\&mid=sec\&sid 1=100\&oid $=001 \&$ aid $=0004418328$ (Accessed: 8 Juni 2020)

Hwang, JiHwan. (2013) "The Two Koreas after U.S. Unipolarity: In Search of a New North Korea Policy", Journal of International and Area Studies, Vol. 20, No. 1, pp. $77-88$.

Kementerian Luar Negeri Korea Selatan. (2020) "North Korea Nuclear Negotiations", Available at:

https: / / nkinfo.unikorea.go.kr/nkp/term/viewKnwldgDicary.do?pageIndex=1 \&dicaryId=92 (Accessed: 8 Juni 2020)

Kementerian Unifikasi Korea Selatan. (2020) "Inter-Korean Conference Information"

Available at:

https://dialogue.unikorea.go.kr/ukd/a/ad/usrtaltotal/List.do

Kim, I. (2014) "Why No Spillover Effect Between The Two Koreas?", The Journal of East Asian Affairs, Vol. 28 No.1, pp. 33-52.

Kudlacova, Lenka. (2014) "South Korean Civil Society Organizations as Confidence-Builders? The Experience with South Korean Civil Society Groupings in the Republic of Korea and the DPRK", Perspectives, Vol. 22, No. 2, pp. 33-64. "Laundering charge hits Macau bank", (2005, 19 September). BBC News (Online) Available at: http://news.bbc.co.uk/2/hi/business/4261450.stm (Accessed: 5 Juni 2020)

Lee, JungHoon and Moon, ChungIn. (2003) "The North Korean Nuclear Crisis Revisited: The Case for a Negotiated Settlement", Security Dialogue Vol. 34, No. 2 (June), pp. 136-151.

Mason, Simon J. A. and Matthias Siegfried. (2013) "Confidence Building Measures (CBMs) in Peace Processes", In: Managing Peace Processes: Process related 
questions. A handbook for AU practitioners, Volume 1, African Union and the Centre for Humanitarian Dialogue

Mihm, S. (2006, 23 Juli) "No Ordinary Counterfeit", The New York Time Magazine (Online)

Available at :

https://www.nytimes.com/2006/07/23/magazine/23counterfeit.html

(Accessed : 5 Juni 2020)

Miryanti, R., \& Pridarita, G. (2020). PERUBAHAN RESPON TIONGKOK TERHADAP UJI COBA NUKLIR KOREA UTARA (2013-2018). Jurnal Dinamika Global, Vol 5 No. 02, pp. 189-218.

Available at :

https://doi.org/10.36859/jdg.v5i02.196 (Accessed: 27 April 2021)

Moon, ChungIn. (2001) "The Kim Dae Jung Government's Peace Policy Toward North Korea", Asian Perspective, Vol. 25, No. 2, Special Issue on Prospects for New Inter-Korean Relations, pp. 177-198.

Moon, ChungIn and Lee, SangKeun. (2009) "Military Spending and The Arms Race on The Korean Peninsula", Asian Perspective, Vol. 33, No. 4, Special issue on Arms Race in Northeast Asia, pp. 69-99.

Mun, SukAhn. (2001) "What Is the Root Cause of the North Korean Nuclear Program?”, Asian Affairs: An American Review, Vol. 38, No. 4 (October-December), pp. 175-187.

Olsen, Edward A. (2003) "A Korean Solution To The United State's Korean Problems", The Journal of East Asian Affairs, Vol. 17, No. 2 (Fall/Winter), pp. 215-240.

Paik, H. (2002) "Assessment of The Sunshine Policy: A Korean Perspective", Asian Perspective, Vol. 26, No. 3, pp. 13-35.

Pemerintah Britania Raya (2004), Appendix 3 Understanding "Political Will" (Online) Available at:

https://assets.publishing.service.gov.uk/media/57a08cbfed915d622c001551 /R8236Appendix3.pdf (Accessed: 11 Maret 2020)

Post, L. A., Raile, A. N. W., \& Raile, E. D. (2010) "Defining Political Will", Politics \& Policy, Vol. 38 No. 4. 
Ryu, GilJae. (2009) "Engagement policy yang berprinsip dalam mengembangkan hubungan inter-Korea", National Assembly Secretariat.

Saeputra, R. (2019) "Pendekatan Konsep Harmoni dalam Manajemen Konflik oleh Jepang dalam Isu Sengketa Senkaku/Diaoyu dengan Tiongkok", Global: Jurnal Politik Internasional, Vol. 20 No.2, pp. 160-199. doi:https://doi.org/10.7454/global.v20i2.330

Sulaiman, V. (2020) "China's Policy in Refusing North Korea Nuclear Proliferation", Global: Jurnal Politik Internasional, Vol. 22, No. 1, pp. 100-124. doi:https: / / doi.org/10.7454/global.v22i1.481

Veronica, N. (2015) "Rivalitas Cina dan Jepang dalam Institusi Regional Asia Timur", Global: Jurnal Politik Internasional, Vol. 16, No. 1, pp.19-33. doi:https://doi.org/10.7454/global.v16i1.9

Yu, SeongWoon. (2014, 23 November) “1999년 1차 연평해전 때 북한 사상자 130여명 달해" 주장 제기", JoongAng Ilbo (Online).

Available at: https://news.joins.com/article/16502965 (Accessed: 8 Juni 2020)

“금강산: 승용차 몰고 갔던 '금강산 관광'... 시설 철거 위기까지”. $(2019,23$ Oktober) BBC Korea (Online)

Available at:

https://www.bbc.com/korean/news-50149119 (Accessed: 26 April 2020)

“북, 핵무기제조 ·보유 공식선언”. (2005, 10 Februari) The Hankyoreh (Online)

Available at:

http://legacy.www.hani.co.kr/section-003000000/2005/02/0030000002005 02101513413.html (Accessed: 8 Juni 2020)

“우리 민족끼리 나아가는 길에 통일의 밝은 미래가 있다”, (2007, 21 Agustus), Committee for the Peaceful Reunification of the Fatherland diakses (Online) Available at:

http:/ /www.uriminzokkiri.com/index.php?ptype=cbooks\&stype=1\&mtype=vie w\&no=516 (Accessed: 4 Mei 2020) 